\title{
32. STRATIGRAPHY AND PLANKTONIC FORAMINIFERS OF NEOGENE AND QUATERNARY SEDIMENTS OF SITE 396, LEG 46 OF DSDP
}

\author{
V. A. Krasheninnikov, Geological Institute of the USSR Academy of Sciences, Moscow, USSR
}

\section{INTRODUCTION}

Site 396 is located on the eastern flank of the Mid-Atlantic Ridge, in the tropical area of the Atlantic Ocean. The drilling by Glomar Challenger in this region was started on Leg 45 . Hole $396\left(22^{\circ} 58.88^{\prime} \mathrm{N}, 43^{\circ} 30.95^{\prime} \mathrm{W}\right.$, $4450 \mathrm{~m}$ water depth) penetrated 125 meters of middle Miocene-Quaternary nannofossil foraminiferal oozes and 96 meters of basalts. The drilling was continued on Leg 46, with two additional holes drilled slightly to the north $\left(22^{\circ} 59.14^{\prime} \mathrm{N}, 43^{\circ} 30.90^{\prime} \mathrm{W}, 4459 \mathrm{~m}\right.$ water depth). Hole 396A penetrated the sedimentary cover, but only two cores of Quaternary sediments (within the 0 to 19 -meter interval) were taken. Hole $396 \mathrm{~B}$ penetrated 150.5 meters of nannofossil foraminiferal ooze and 256 meters of basalts; three cores of lower Pliocene sediments were taken (122.0 to $150.5 \mathrm{~m}$ sub-bottom).

The stratigraphic subdivision of Miocene, Pliocene, and Quaternary sediments by means of planktonic foraminifers in Hole 396 was given in the Initial Reports of the DSDP, Leg 45 (Krasheninnikov, 1978). This article summarizes very briefly all the stratigraphic data obtained for Holes $396,396 \mathrm{~A}$, and 396B; the general idea about the main features of microfauna, the character of sediments, and a comparison with the Pliocene-Quaternary section of Site 395 on the west flank of the Mid-Atlantic Ridge are given as well.

\section{ZONAL STRATIGRAPHY OF NEOGENE AND QUATERNARY SEDIMENTS OF SITE 396}

The Site 396 site chapter (this volume) indicates the presence of thin intercalations of sediments interbedded with basalts. Thus, notable pieces occur in the top of the sparsely phyric unit (Cores 396B-5 and 396B-6), sometimes mixed with palagonite to form the breccia. A piece of sediment ( $3 \mathrm{~cm}$ thick) separates basalts in Core 396B-13. The sediments are represented by well-lithified nannofossil oozes with rare preserved foraminifer outlines. In the basaltic sands of Core 396B-30 ( 377 to $382 \mathrm{~m}$ sub-bottom), foraminifers have been found and sampled for a shore-based analysis.

This study focuses on the foraminifers from Core 396B-30 that we had at our disposal. The assemblage consists of well-preserved tests of Globigerinoides conglobatus, G. ruber, G. sacculifer, Orbulina universa, Sphaeroidinella dehiscens, Globorotalia crassaformis, G. tumida, and Globigerina bulloides that are typical for sediments of Pliocene-Quaternary time. The age of this foraminiferal assemblage is younger, as compared with that of the basal layers of the sedimentary cover in Hole 396 (middle Miocene). Taking into account the biostratigraphic data and excellent preservation of foraminifers, it is reasonable to assume uphole contamination.

Basalts are covered by a pile of biogenic oozes; their thickness in Holes 396 and 396B is 125 and 151 meters, respectively. The character of the basalt/sediment contact could be carefully examined in Hole 396 . Sediments above the basalts are not metamorphosed, and the contact can be considered normal, i.e., depositional. The character of the basalt/sediment boundary in Hole 396B is unknown, because the sediments near the contact were not preserved in the process of drilling; in any case, the nearest sediments do not display traces of any thermal metamorphism.

The sedimentary pile can be subdivided into two lithological units. The lower one ( $8 \mathrm{~m}$ thick in Hole 396 and $13 \mathrm{~m}$ thick in Hole 396B) is composed of yellow and brownish clayey nannofossil oozes and calcareous clays. The upper unit (117 m thick in Hole 396 and $138 \mathrm{~m}$ thick in Hole 396B) consists of grayish, yellowish, and pale brownish nannofossil and nannofossil foraminiferal oozes. This unit represents an alternation of normal pelagic biogenic oozes and calcareous turbidites with redeposited and well-sorted fossils. Abundant planktonic foraminifers within the sedimentary pile allow distinction of subdivisions of the middle Miocene, Pliocene, and Quaternary.

\section{Middle Miocene}

Sediments of this age correspond to the Globorotalia fohsi fohsi Zone with the index-species, G. peripheroronda, G. peripheroacuta, G. siakensis, Orbulina suturalis, Globigerinoides trilobus, Globigerina bollii, G. druryi, Globoquadrina dehiscens, and G. altispira. Among specimens of Sphaeroidinellopsis, only the species Sph. seminulina has been determined. The absence of Sph. subdehiscens prevents assignment of the sediments to the next (younger) Sphaeroidinellopsis subdehiscensGlobigerina druryi Zone. Thickness is not over 4 to 4.5 meters (from Samples 396-14-5, 144-146 cm to 396-14-3, 99-101 cm).

\section{Upper Miocene-Lower Pliocene}

Upper layers of brownish calcareous clays and clayey nannofossil oozes include poor assemblages of planktonic foraminifers, i.e., Sphaeroidinellopsis subdehiscens, Sph. seminulina, Globigerinoides conglobatus, G. ruber, G. sacculifer, Globigerina nepenthes, Globoquadrina dehiscens, $G$. altispira, Globorotalia menardii, and $G$. dutertrei. They can be assigned to the uppermost Miocene (the Globorotalia margaritae margaritae Zone) and the lower Pliocene (the Globorotalia margaritae evoluta Zone) from Samples 396-14-2, 90-92 cm to 396-13-6, 146-148 $\mathrm{cm}$. 
Consequently, the two above-mentioned stratigraphic subdivisions in Hole 396 are separated by a gap; the upper part of the middle Miocene (the Sphaeroidinellopsis subdehiscens-Globigerina druryi and Globigerina nepenthes-Globorotalia siakensis zones) and almost the entire upper Miocene (the Globorotalia continuosa, Globorotalia merotumida, Globorotalia plesiotumida, and part of the Globorotalia margaritae margaritae zones) are missing.

In Hole 396B, there is an 8-meter interval without recovery between basalts and nannofossil foraminiferal oozes of the lower Pliocene (the Globorotalia margaritae evoluta Zone). Evidently, this uncored interval corresponds to the middle Miocene and undifferentiated upper Miocene-lower Pliocene sediments of Hole 396.

The sequence of Pliocene and Quaternary sediments of Site 396 is continuous, so all zonal and subzonal units can be singled out.

\section{Pliocene}

Rich assemblages of planktonic foraminifera allow these zones to be recognized easily:

1) The Globorotalia margaritae evoluta Zone includes the index-species $G$. tumida, $G$. margaritae margaritae, $G$. pseudomiocenica, $G$. menardii, $G$. dutertrei, $G$. crassaformis crassaformis, G. crassaformis ronda, Sphaeroidinella dehiscens, Sphaeroidinellopsis seminulina, Sph. subdehiscens, Globigerina nepenthes, Globoquadrina alti 'ra, G. dehiscens, Globigerinoides conglobatus, $G$. ruber, $G$. sacculifer, and $G$. obliquus extremus. This interval ranges from Samples 396-13-5, 109-111 cm to $396-11-6,89-91 \mathrm{~cm}$; and 396B-3-1, 134-136 cm to 396B-2-1, 108-110 cm.

2) The Globorotalia miocenica Zone includes the index-species $G$. exilis, $G$. pertenuis, $G$. pseudomiocenica, $G$. dutertrei, $G$. crassaformis crassaformis, $G$. crassaformis ronda, G. crassaformis oceanica, Candeina nitida, Pulleniatina obliquiloculata, Sphaeroidinella dehiscens, Globigerinoides conglobatus, and G. ruber, $G$. sacculifer. Very rare specimens of Globorotalia multicamerata and Globigerinoides trilobus fistulosus have been found in the lower part of this zone. This interval ranges from Samples 396-11-4, 134-136 cm to 396-8-2, $73-75 \mathrm{~cm}$.

3) The Globorotalia tosaensis Zone includes the index-species $G$. dutertrei, G. hirsuta, G. crassaformis crassaformis, G. crassaformis viola, G. crassaformis ronda, Orbulina universa, Sphaeroidinella dehiscens, Candeina nitida, Globigerinoides conglobatus, G. ruber, $G$. sacculifer, Globigerinella siphonifera, and Globigerinita uvula. This interval ranges from Samples $396-7-6,74-76 \mathrm{~cm}$ to $396-5-3,125-127 \mathrm{~cm}$.

\section{Quaternary}

The normal succession of stratigraphic subdivisions testifies to a gradual transition of the Pliocene sediments (the Globorotalia tosaensis Zone) to the Quaternary ones (the Globorotalia crassaformis viola Subzone). Poor recovery at the Pliocene/Quaternary boundary did not permit fixing this boundary exactly.
Quaternary sediments correspond to the Globorotalia truncatulinoides Zone which is characterized by abundant planktonic foraminifers: Globorotalia truncatulinoides, $G$. crassaformis s.l., G. menardii, G. dutertrei, G. ungulata, G. tumida, Candeina nitida, Globigerinoides conglobatus, G. sacculifer, G. ruber, Pulleniatina obliquiloculata, Sphaeroidinella dehiscens, Globigerina rubescens (white), $G$. bulloides, and Globorotaloides variabilis.

The Globorotalia truncatulinoides Zone is subdivided into three subzones:

1) The Globorotalia crassaformis viola Subzone which is determined by the coexistence of subspecies $G$. tosaensis and $G$. truncatulinoides. This subzone ranges from Samples $396-3-3,86-88 \mathrm{~cm}$ to $396-2-5,139-141 \mathrm{~cm}$.

2) The Globorotalia crassaformis hessi Subzone with the given subspecies developed; Gl. crassaformis viola is practically absent, except for very rare specimens in the basal layers of this subzone. This subzone spans Samples $396-2-4,83-85 \mathrm{~cm}$ to $396-1-2,121-123 \mathrm{~cm}$.

3) The Globigerina calida calida Subzone with rare specimens of $G$. aff. calida calida accompanied by pink Globigerina rubescens and Globigerinoides ruber, together with Globorotalia tumida flexuosa. This subzone is observable in Samples 396A-1-1, 139-141 cm; 396A-1-1, $129-130 \mathrm{~cm}$; and 396-1-1, 139-141 cm.

The youngest Quaternary sediments (the Globigerina bermudezi and the Globorotalia fimbriata subzones) have not been discovered in Site 396.

\section{PECULIARITIES OF FORAMINIFER DISTRIBUTION IN THE CENOZOIC SEDIMENTS OF SITE 396}

Two types of foraminiferal associations have been established in the Cenozoic sediments of Site 396. The first type can be qualified as the natural assemblages (paleocoenoses) of planktonic foraminifers, generally reflecting their composition in the upper layer of the water columns of the appropriate time. These assemblages consist of the species of Globorotalia, Globigerina Globigerinoides, Orbulina, Globigerinita, Globorotaloides, Sphaeroidinella, Sphaeroidinellopsis, Globigerinella, Candeina, and Pulleniatina typical of the Neogene and Quaternary sediments of the tropical and subtropical areas. Based on the given assemblages, zonal and subzonal subdivisions of the Cenozoic stratigraphic scale have been recognized: the Globorotalia fohsi fohsi Zone (middle Miocene); the Globorotalia margaritae evoluta, Globorotalia miocenica, and Globorotalia tosaensis zones (Pliocene); and the Globorotalia truncatulinoides Zone with Globorotalia crassaformis viola, Globorotalia crassaformis hessi, and Globigerina calida calida subzones (Quaternary).

The middle Miocene is represented by the Globorotalia fohsi fohsi Zone only. Therefore, the evolutionary lineage of the Globorotalia fohsi group cannot be traced here. Nevertheless, the presence in some samples of $G$. peripheroronda, $G$. peripheroacuta, and $G$. fohsi fohsi indirectly testifies to this lineage.

In some regions of the Atlantic Ocean, Globorotalia tosaensis is lacking (or very rare) in upper Pliocene 
sediments. This species is common for the area of Site 396, allowing observation of the $G$. tosaensis-G. truncatulinoides lineage and precise determination of the Pliocene/Quaternary boundary. It is an example of the irregular distribution of planktonic foraminifers which should be taken into consideration in the process of stratigraphic investigations and application of zonal names. All subspecies of Globorotalia crassaformis (crassaformis, ronda, oceanica, viola, and hessi) are very well developed in the Pliocene-Quaternary sediments of Site 396. The lineage of the Globorotalia crassaformis group is clearly observed here, and enables subzones within the Quaternary sediments to be singled out.

The distribution of planktonic foraminifers in the Cenozoic sediments of Site 396 is shown in Table 1.

The sediments with the above-mentioned paleocoenoses of planktonic foraminifers can be treated as normal pelagic deep-water biogenic oozes.

Planktonic foraminiferal assemblages of the second type are of the heterogenic character. They include a number of foraminifers redeposited from more ancient deposits and also display a well-pronounced sorting of tests according to their size. Sometimes these assemblages consist of enormous quantities of minute and juvenile tests of Globigerina, Globigerinita, and Globigerinoides that create difficulties for age determination; in other cases, the assemblages, formed by big tests of Orbulina, Globigerinoides, Sphaeroidinella, Globorotalia, and Pulleniatina, resemble foraminiferal sands. It is quite evident that sediments with such assemblages of planktonic foraminifers can be treated as calcareous biogenic turbidites originated in connection with turbidity currents down the eastern slope of the Mid-Atlantic Ridge.

Sediments with heterogenic assemblages of planktonic foraminifers were met in all subdivisions of the Pliocene and Quaternary: the Globorotalia margaritae evoluta Zone (in Samples 396-13-3, 66-68 cm and 396B-2-1, 108-110 $\mathrm{cm}$ ); the Globorotalia miocenica Zone (Samples 396-10-5, $108-110 \mathrm{~cm}$; 396-10-3, 120-122 cm; 396-9-4, 64-66 cm; and 396-9-2, 8-10 cm); the Globorotalia tosaensis Zone (Samples 396-7-2, 96-99 cm; 396-6-6, 86-88 cm; 396-6-4, 105-107 cm; 396-6-2, 82-84 cm; 396-5-5, 74-76 cm; $396-5-3,125-127 \mathrm{~cm}$; and $396-5-1,116-118 \mathrm{~cm}$ ); the
Globorotalia crassaformis viola Subzone (Samples 396-3-3, 86-88 cm; 396-3-1, 87-89 cm; and 396-2-5, $139-141 \mathrm{~cm}$ ); the Globorotalia crassaformis hessi Subzone (Samples 396-2-1, 123-125 cm and 396-2-4, 83-85 cm); and the Globigerina calida calida Subzone (Samples $396 \mathrm{~A}-1-1,139-141 \mathrm{~cm}$ and 396-1-1, 129-130 cm).

Consequently, bottom turbidity currents were acting in the course of the entire Pliocene-Quaternary time, but were not constant. The latter accounts for the alternation of calcareous turbidites with normal pelagic biogenic oozes. Obviously, the most active turbidity currents were in the upper Pliocene time (the Globorotalia tosaensis Zone) and in the lower Quaternary time (the Globorotalia crassaformis viola Subzone).

It should be noted that it is rather difficult to estimate the scope of redeposited material because stratigraphic ranges of many foraminiferal species correspond to the whole Pliocene-Quaternary interval. The state of preservation cannot help in this case; undoubtedly, reworked species of planktonic foraminifers (species of Sphaeroidinellopsis, Globigerina nepenthes, Globorotalia miocenica, G. exilis, $G$. multicamerata, $G$. pertenuis, etc.) are characterized by the same excellent preservation as the species found in situ.

Certainly, wide development of heterogenic assemblages of planktonic foraminifers prevents an exact determination of the position of stratigraphic boundaries.

Analogous calcareous turbidites alternating with normal pelagic oozes are widely developed at Site 395 on the western flank of the Mid-Atlantic Ridge (Figure 1). The thickness of Pliocene-Quaternary sediments in Sites 395 and 396 is rather significant: 84 and 115 meters, respectively. A comparatively high rate of sedimentation of calcareous material is connected, evidently, with a pronounced input of reworked organic remains.

\section{REFERENCES}

Krasheninnikov, V. A., 1978. Stratigraphy of Neogene and Quaternary sediments by means of planktonic foraminifers near the crest of the Mid-Atlantic ridge, Sites 395 and 396, Leg 45 of DSDP. In Melson, W. G., Rabinowitz, P. D., et al., Initial Reports of the Deep Sea Drilling Project, v. 45: Washington (U.S. Government Printing Office). 
TABLE 1

Distribution of Planktonic Foraminifers in the Cenozoic Sediments of Site 396, Leg 46

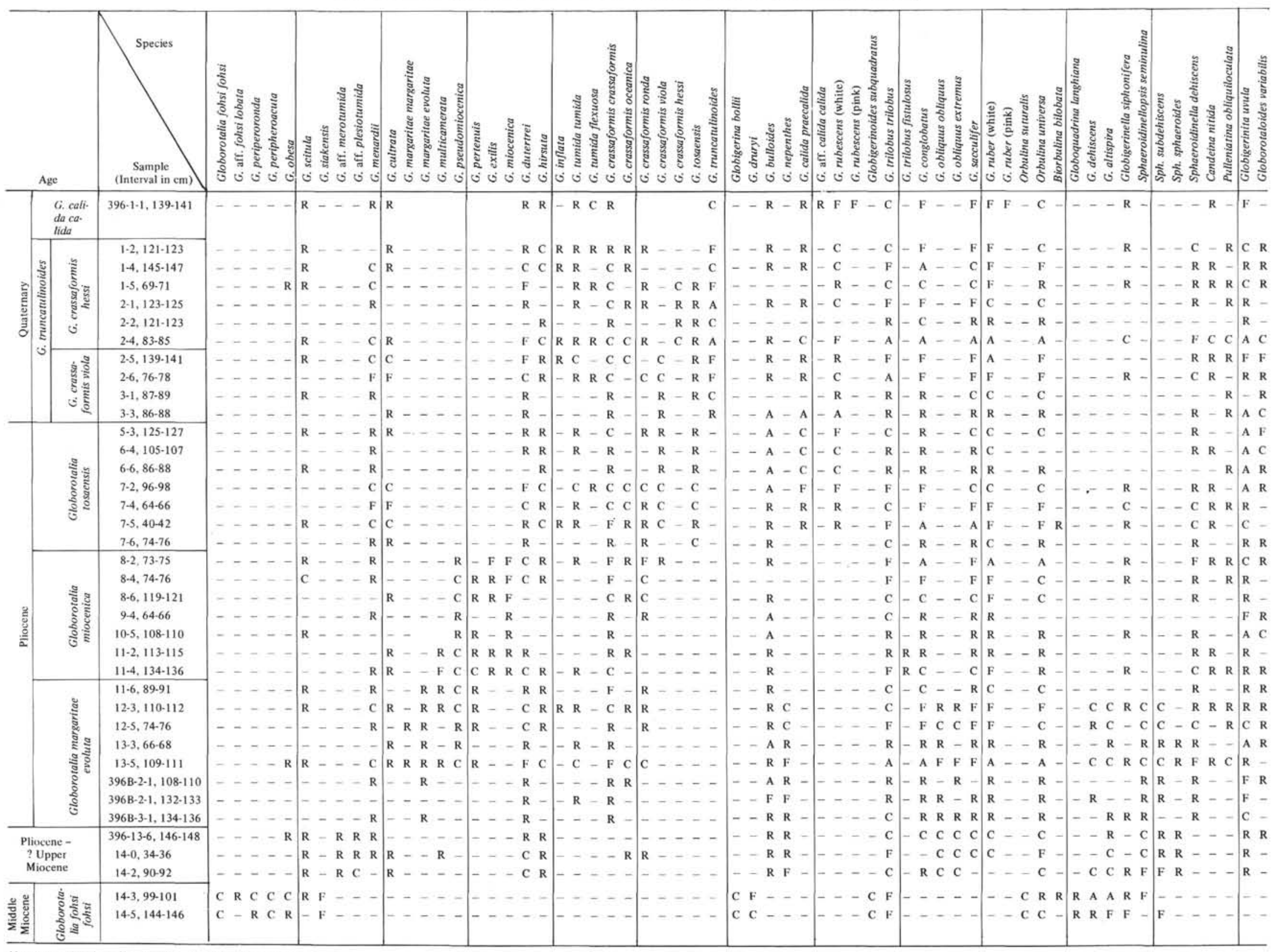



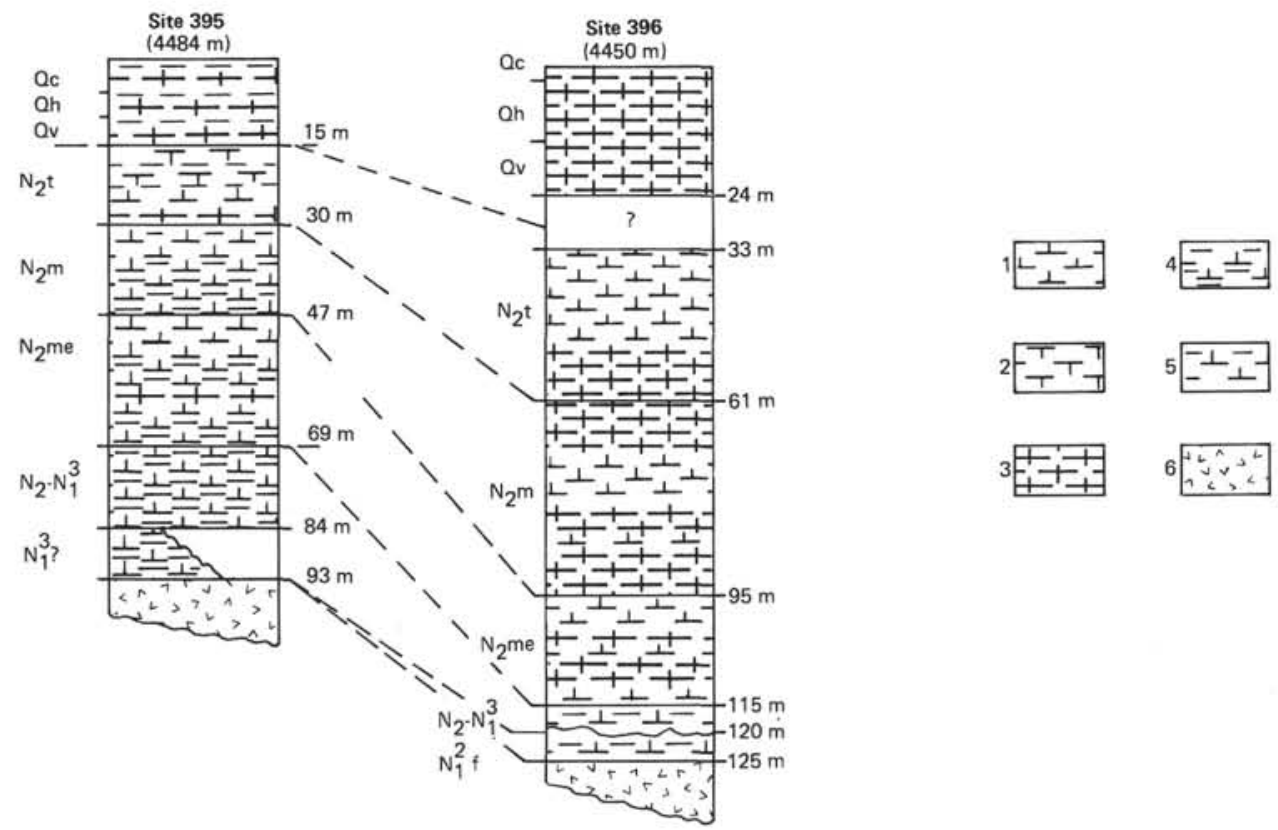

Figure 1. Stratigraphic correlation of the Cenozoic sediments of Sites 395 and 396, Leg 45 and Leg 46. Lithologic symbols: 1 = nannofossil oozes, 2 = foraminiferal oozes, $3=$ nannofossil foraminiferal oozes, $4=$ clayey nannofossil and nannofossil foraminiferal oozes, $5=$ calcareous clays with nannofossils and foraminifers, $6=$ basalts. Stratigraphic symbols: Quarternary: $Q c=$ the Globigerina calida calida Subzone; $Q h=$ the Globorotalia crassaformis hessi Subzone; $Q v=$ the Globorotalia crassaformis viola Subzone; Pliocene: $\mathrm{N}_{2} t=$ the Globorotalia tosaensis Zone; $N_{2} m=$ the Globorotalia miocenica Zone; $N_{2}$ me = the Globorotalia margaritae evoluta Zone; $N_{2}-N_{1}^{3}=$ undifferentiated basal Pliocene and the uppermost Miocene. $N_{1}^{3}$ ? = Upper Miocene? $N_{2}^{l} f=$ Middle Miocene, the Globorotalia fohsi fohsi Zone. 